application of $100 \mathrm{ml}$ of pesticide proved stressful to trees already growing under poor conditions (sometimes water-logged and lacking fertilizer) or a biological agent was affected. Predators are thought to have little influence on coconut mite levels, but their effect is difficult to quantify. Possibly predators were reduced by eating coconut mites that had taken up some vamidothion: however, there is no evidence to support either of these suggestions. The greater number of young nuts from the vamidothion-treated trees (Table 3) did not reflect control of mites as damage levels were worse with the treatment, though the pesticide may have killed other incidental sucking pests such as scales. The results at Choc Estate did suggest an effect of the vamidothion, even when applied 1 month after drilling the trees.

The results from Fond Estate were somewhat contradictory, although again they provided no positive support for pesticide use. Although the treated trees appeared to have produced more nuts (Table 7), the damage results do not suggest that this was due to mite control; again, incidental pests may have been controlled.

The delay in applying pesticide after drilling at Choc Estate may have impeded uptake but circumstantial evidence suggests that the pesticide was taken up. For example, the level of pesticide in the holes' dropped over a matter of a few hours and within a week a very dilute concentration was present. Additionally, the results from Choc Estate suggest an effect of the pesticide. It is possible that embolism occurring at drilling could be overcome by the high root pressures that occur in palms (Davis, 1961), especially with the interconnecting nature of the vascular tissues. At Fond Estate the pesticide was added soon after drilling and still did not produce evidence of control.

Coconuts are a very valuable crop in St Lucia and other Windward Islands and the mite is causing serious financial loss. As such, well-publicized methods of control receive a great deal of support, even without careful examination of the experimental proof. Griffith (1982, 1983, 1984) worked on young short trees, which may explain differences from the present work. However, his claims for the pesticide were not justified by the data that he presented, nor by the manner in which the experiments were conducted. For example one of Griffith's main experiments (Griffith, 1982) had no control trees with which to make valid comparisons and no yield data have been produced from the experiments. Other data do not stand up to critical analysis and some claims are obviously false.

Although there is evidence that chemicals can control the coconut mite (Hernandez, 1977; Julia and Mariau, 1979) they normally have to be applied at uneconomic intervals while the treatments are con- sidered too damaging for older trees. In these two trials the single applications of vamidothion to medium-aged and old trees in St I.ucia were unsuccessful. As most trees in the island are 30-50 years old, as is the case with some other Windward Islands, it is unlikely that the use of vamidothion would have beneficial results. Proposals for the use of vamidothion should be closely examined for new evidence showing jt5 value and should not be based on previous clainrs.

\section{Aqknowledgements}

The Government of $S t I$ ucia provided the facilities for the project which was funded by the Food and Agricultural Organization of the United Nations. Thanks are due to P'aul Adlieh, Paul Alexander, Lester Biscette and Titus Philip for cheerful and able assistance in the ficld work.

\section{References}

DAvis, $\tau_{2}$ A. (1961): High root pressures in palms. Nature 192, $277-278$.

D) KKFSTE, E. S. (1968). El acaro de la flor del cocotero (Aceria gkerreronis) en Venezuela. Agronomiá Tropical 18, 279-386.

GRIlilinH, R. (1982). The development of a programme for the control of the coconut mite Eriophyes guerreromis Keifer in the coconut groves of the island of St. Vincent, W'.I. In: P'erspective's of Cacomut Pests and Discases in the W'est Indies (and Adjacent Lands), pp. 57-63. Georgetown, Ciuyana: Caricom Secretariat.

(SRllilTH, R. (1983). The coconut mite, Eriophyes guerreronis Keifer in the coconut groves of I atin America. In: $W^{\prime}$ urkshop on Agricultural Research Policy and Munagement in the Caribbean, pp. 42-47. United Nations Econornic Commission for I.atin America.

Q guerreronis (Keifer), in the coconut groves of Trinidad and Tobago. In: Proceedings of the 20/th Annual Meeting of the Caribbean Food Crops Society, St Croix, IS Virgin Islands, 21-26 Oclober 1984, pp. 128-132 (ed. by R. Webb, W. Knausenberger and L. Yntema). Eastern Caribbean Center, College of the Virgin Islands and Caribbean Food Crops Society.

Hernande7, R. F. (1977). Combate quimico de eriófido del cocotero Aceria (Eriophyes) guerreronis (K) en la Costa de Guerrero. Agricultura Téchnica en México 4, 23-28.

JL. IA, J.F. ANI) MARIAC, D. (1979). Nouvelles recherchè en Côte d'Ivoire sur Eriophyes guerreronis K., acarien ravageur des noix cocotier. Oléagineux 34, 181-189.

MARIAL, D. (1977). Aceria (Eriophyes) guerreronis: un important ravageur des cocotieraies africaines et américaines., Oléagineux $32,101-111$.

MARIAC, D. AND JLL.1A, J-F. (1970). L'acariose à Aceria guerreronis (Keifer) ravageur du cocotier. Oléagineux 25, 459-464.

Received 8 September 1986

Revised 13 February 1987

Accepted 9 March 1987 


\title{
Chemical control of sorghum head bugs (Hemiptera: Miridae)
}

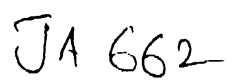

\author{
H. C. SiIARma AND K. Leuscinner
}

\author{
International Crops Research Institute for the Semi-Arid Tropics (ICRISAT) Patancheru \\ $P O, 502324 A P$, India
}

\begin{abstract}
ABSTRAC:I. Eight contact and three systemic insecticides, and an enriched neem extract were tested for the control of sorghum head bug, Calocoris angustatus Leth. at the ICRISAT Center. The insecticides were applied at the complete-anthesis and milk stages (at $500 \mathrm{l} / \mathrm{ha}$ ) with a knapsack sprayer. On the basis of effectiveness of head bug control, grain yield and 1000-grain mass, carbaryl (at $500 \mathrm{~g}$ a.i./ha) was the most effective insecticide followed by fenvaleratc (at $50 \mathrm{~g}$ a.i./ha), and chlorpyrifos (at $250 \mathrm{~g}$ a.i./ha). Among the systemic insecticides, demeton-S-methyl (at $250 \mathrm{~g}$ a.i./ha) was the most effective. Demeton-S-methyl and dimethoate were also effective for the control of other head bug species-Eurystylus bellevoyei Put. and Reut. and Campylomma sp. Plots sprayed with demeton-Smethyl gave higher grain yields than those treated with carbaryl, which was the best contact insecticide. Two sprays of carbaryl (at $500 \mathrm{~g}$ a.i./ha) applied at the complete-anthesis and milk stages have been found to be effective for head bug control. Dichlorvos, fenitrothion and monocrotophos were highly phytotoxic and resulted in burning and drying of entire leaves. Dimethoate resulted in a slight drying of leaf tips and margins.
\end{abstract}

KHYW'ORISs: Sorghum; head bugs; chemical control; insecticides

\section{Introduction}

Sorghum is the third most important cereal crop in India after rice and wheat. Insect pests are one of the most important factors limiting sorghum production on the farmers' ficlds in the semi-arid tropics. The mirid head bugs, Calocoris angustatus Leth., Eurystylus bellevoyei Put. and Reut., Creontiades pallidus Ramb. and Campylomma sp. are important pests of developing sorghum grain in India and result in severe loss in grain yicld and quality. Sorghum midge, Contarinia sorghicola Coq. and the bollworm, Heliothis armigera $\mathrm{Hb}$. are other important pests which feed on sorghum panicle from flowering to the hard-dough stage.

Calocoris angustatus is the predominant head bug species in India. Both the adults and nymphs feed on the sorghum panicle from the time of emergence to the hard-dough stage. Eggs are laid in the florets from panicle emergence to sho: ly after anthesis. Damage during the early stages of grain development may result in a complete loss of grain, while the grains damaged during the milk stage shrivel, and remain small. Under low levels of infestation the grain may develop normally but shows distinct brown feeding punctures, which affect the food quality both in terms of consumer acceptance and nutritional value (Sharma,
1985).

Because of the limited possibility of success with host-plant resistance as a method of reducing head bug damage (Sharma, 1985), chemical control may become necessary in situations of moderate to high levels of head bug damage. Very little information is available on the chemical control of head bugs. Cherian, Kylasam and Krishna (1941) recommended sulphur dusting while Puttarudraiah (1947) suggested dusting of powdered tobacco (mixed with soap in the ratio of 1:1). David, Sivagami and Janagarajan (1969) found that carbaryl gave effective control of head bug. Paul, Subba Rao and Narayana (1983) reported that dusts of phenthoate, carbaryl, malathion and quinalphos, and sprays of chlorpyrifos, leptophos and carbaryl were highly effective against head bug; in those studies, the exact crop stage and number of sprays required were not mentioned. Studies at the International Crops Research Institute for the Semi-Arid Tropics (ICRISAT) Center were carried out to compare the relative effectiveness of eleven insecticides and an enriched extract of neem (Azadirachta indica A. Juss) kerneis, and to determine the optimum insecticide dosage, optimum stage of panicle development for spraying, and the number of sprays required for effective head bug control. 


\section{Materials and methods}

The experiments were conducted on a commercial sorghum hybrid (CSH 1). Four infester rows of mixed maturity head bug susceptible sorghum hybrids (CSH 1: CSH 5,1:1) were planted 20 days before the experimental plots. The infester rows were sown after every 16 rows. The crop was planted on ridges $75 \mathrm{~cm}$ apart, and plants were thinned to $10 \mathrm{~cm}$ spacing within the rows 15 days after emergence. Carbofuran $3 G$ (at $40 \mathrm{~kg} / \mathrm{ha}$ ) was applied at the time of sowing to protect the seedlings from sorghum shoot fly (Atherigona soccata Rond.) and spotted stem borer (Chilo partellus Swin.) damage. The experiments were laid out in a randomized block design.

Head bugs collected from other fields were uniformly spread in the infester rows at the time of panicle emergence. The head bugs multiplied for one generation on the infester rows and then moved to the test plots. This provided a uniform infestation and increased the head bug abundance in the experimental plots.

The insecticides were sprayed at $500 \mathrm{l} / \mathrm{ha}$ with a knapsack sprayer having a hollow cone nozzle, and a pump pressure of $2 \cdot 5-3 \cdot 0 \mathrm{~kg} / \mathrm{cm}^{2}$. A $2 \times 2 \mathrm{~m}$ polyethylene screen was held down wind to minimize the insecticide drift to the adjacent plots. The infester rows also helped to prevent the spray drift.

Head bugs were counted in 10 randomly selected panicles in each plot before and/or $24 \mathrm{~h}$ after each spraying at different stages of panicle development. Data were also recorded on other head bug species, sorghum midge, and the bollworm, whenever their incidence became high. At maturity, sorghum panicles in the central four rows were harvested to record grain yield and 1000-grain mass in each plot. Data on 1000-grain mass were not recorded in experiments conducied during the 1985 rainy season. Data were analysed statistically to determine the least significant differences between treatments. Data on head bug numbers were transformed into $\sqrt{n}$ or $\sqrt{n+1}$ before statistical analysis.

\section{Relative effectiveness of insecticides}

Eight insecticides-carbaryl (1-naphthyl methylcarbamate), endosulfan $((1,4,5,6,7,7$-hexachloro8,9,10-trinorborn-5-en-2,3-ylenebismethylene) sulphite), malathion (diethyl(dimethoxyphospinothioylthio)succinate), quinalphos $(0, O$-diethyl $O$ quinoxalin-2yl phosphorothioate), dichlorvos (2,2-dichlorovinyl dimethyl phosphate), chlorpyrifos (O,O-diethyl $\mathrm{O}$-(3,5,6-trichloro-2-pyridyl phosphorothioate), fenitrothion ( $O, O$-dimethyl $O-4$-nitro-m-tolyl phosphorothioate), fenvalerate ((RS)- $\alpha$-cyano-3phenoxybenzyl (RS)-2-(4-chlorophenyl)-3-methylbutyrate)-and an enriched neem extract from seeds (Sharma et al., 1984) were tested, together with an untreated control during the 1982 rainy season (JuneOctober). There were three replications and each plot measured $54 \mathrm{~m}^{2}$. The insecticides were sprayed at the complete-anthesis and milky stages. Five insecticides were retested during the 1983 rainy season, on the basis of their effectiveness for head bug control.

During the 1984 and 1985 rainy seasons, three systemic insecticides-demeton-S-methyl (S-2-ethylthioethyl $O,($-dimethyl phosphorothioate), dimethoate $(0,0$-dimethyl $S$-methylcarbamoylmethyl phosphorodithioate), and monocrotophos (dimethyl (E)-1-methyl-2-(methylcarbamoyl)vinyl phosphate)were evaluated for head bug control together with carbaryl and an untreated control. Each plot measured $54 \mathrm{~m}^{2}$ and there were three replications. Head bugs were counted in five randomly selected panicles at the complete-anthesis and the milk stages.

\section{Insecticide dosage required}

On the basis of the relative effectiveness of insecticides for head bug control, carbaryl was selected for detailed studies on the rate of application, optimum stage of panicle for spraying and the number of sprays required for head bug control. Four dosages of carbaryl (250), 500,1000 and $2000 \mathrm{~g}$ a.i./ha) together with an untreated control were tested on CSH 1 under field conditions during the 1983 and 1985 rainy season. There were four replications. Each plot measured $90 \mathrm{~m}^{2}$ during the 1983 and $54 \mathrm{~m}^{2}$ during the 1985 rainy season. The crop was sprayed twice at the completeanthesis and milk stages. Head bugs were counted $24 \mathrm{~h}$ after each spraying.

\section{Optimum stage of panicle development for spraving}

To determine the optimum stage of panicle for protection against head bugs, carbaryl at $500 \mathrm{~g}$ a.i./ha was sprayed once at the top-anthesis, complete-anthesis or milk stage during the 1983 and the 1985 rainy seasons. Untreated plots were kept as controls. There were four replications. Each plot measured $90 \mathrm{~m}^{2}$ during the 1983 and $54 \mathrm{~m}^{2}$ during the 1985 rainy season. Head bug numbers were counted $24 \mathrm{~h}$ after each spraying at the top-anthesis, complete-anthesis and milky stages.

\section{Number of insecticide sprays}

The effectiveness of three spray schedules of carbaryl (at $500 \mathrm{~g}$ a.i./ha) was evaluated for head bug control on $\mathrm{CSH} 1$. The crop was sprayed at the half:anthesis, halfanthesis and complete-anthesis, or at the half-anthesis, complete-anthesis and milky stages. There were four replications and each plot measured $90 \mathrm{~m}^{2}$ during the 1983 and $54 \mathrm{~m}^{2}$ during the 1985 rainy season. Grain yield was recorded in the central six rows.

\section{Results}

\section{Relative effectiveness of insecticides}

Results on the relative effectiveness of different insecticides for head bug control are given in Tables 1 
to 4 . During the 1982 rainy season, there were $24-31$ head bugs per panicle before spraying; the infestation levels therefore were quite uniform and high. All insecticides reduced the head bug numbers significantly over the untreated plots. However, the decrease in head bug numbers was not observed in neem-treated plots after the second spraying. The head bug numbers increased substantially 10 days after the first spraying. However, the increase in head bug density was lower ( $<22$ head bugs per panicle) in carbaryl- and chlorpyrifos-treated plots compared with untreated plots ( 73 head bugs per panicle). The incidence of $C$. pallidus, $E$. bellevoyei, Campylomma sp. and $H$. armigera was less than one insect per panicle. Midgedamaged chaffy florets ranged from $13 \%$ to $20 \%$, and the differences were not significant between the treatments. The maximum grain yield was recorded in fenvalerate-treated plots $(1780 \mathrm{~kg} / \mathrm{ha})$, followed by those treated with carbaryl $(1690 \mathrm{~kg} / \mathrm{ha})$ and malathion $(1490 \mathrm{~kg} / \mathrm{ha})$. The 1000 -grain mass was maximum in carbaryl-treated plots (Table 1).

Five insecticides (carbaryl, fenvalerate, malathion, quinalphos and chlorpyrifos) which were effective for head bug control during the 1982 rainy season were retested during the 1983 rainy season. All the insecticides reduced head bug numbers significantly compared with the untreated control plots ('Table 2). Head bug numbers in samples collected from the untreated control plots were also lower after first spraying, possibly because of the nature of the population distribution (the insects are generally distributed in patches) or some mortality of head bugs due to insecticide drift. Midge damage ranged from 5\% to $10 \%$ and the differences were not significant between the treatments. The incidence of other head bug species and of H. armigera was negligible. Carbaryl-treated plots gave the maximum grain yield $(2400 \mathrm{~kg} / \mathrm{ha})$ followed by those treated with fenvalerate $(2360 \mathrm{~kg} / \mathrm{ha})$ and chlorpyrifos $(2350 \mathrm{~kg} / \mathrm{ha})$. The 1000-grain weight was highest in carbaryl-treated plots followed by those treated with quinalphos. Carbaryl, fenvalerate and chlorpyrifos were the most effective insecticides for head bug control.

Results relating to the relative effectiveness of systemic insecticides are presented in Tables 3 and 4. There were 1-2 C. angustatus adults per panicle at the complete-anthesis stage before spraying. All insecticides reduced the head bug numbers significantly over the untreated control, of which demeton-S-methyl was the most effective (less than one head bug per panicle) followed by monocrotophos, dimethoate and carbaryl (Table 3). At the milk stage, the head bug numbers increased substantially in dimethoate- and carbaryltreated plots (15-28 head bugs/panicle) compared with plots treated with demeton-S-methyl and monocrotophos (four head bugs per panicle). The numbers

'TABI 1: 1. Relative ellectiveness of I wo sprays of some insecticides for head bug control in sorghum hybrid (SSH 1 (1982 rainy season)

\begin{tabular}{|c|c|c|c|c|c|c|c|}
\hline \multirow[b]{2}{*}{ Insecticide } & \multicolumn{6}{|c|}{ No. of head bugs per panicle } & \multirow[b]{2}{*}{$\begin{array}{c}1000 \text {-grain I } \\
(\mathrm{g})\end{array}$} \\
\hline & $\begin{array}{l}\text { Dosage } \\
\text { (g a.i./ha) }\end{array}$ & Bomplet & $24 \mathrm{~h}$ after spray & Before spray & $24 \mathrm{~h}$ after spray & $\begin{array}{c}\text { Grain yicld } \\
(\mathrm{kg} / \mathrm{ha})\end{array}$ & \\
\hline Carbaryl & $5(0)$ & $26(5 \cdot 1)^{4} \mathrm{a}$ & $1(1 \cdot 1)^{\star} a$ & $21(4 \cdot 6)^{\star}$ & $1(0 \cdot 5)^{\star} \mathrm{a}$ & $1690 \mathrm{~b}$ & $29 \cdot 4 c$ \\
\hline Fenvalerate & 50 & $29(5.4) \quad \mathrm{a}$ & $1(1 \cdot 2) \quad a$ & $57(7 \cdot 4) \quad a b$ & $1(0 \cdot 7)$ ab & $1780 \mathrm{~b}$ & $25 \cdot() \mathrm{bc}$ \\
\hline Chlorpyrifos & 250 & $30(5 \cdot 5)$ a & $1(1 \cdot 3)$ a & $22(4 \cdot 7)$ & $2(1 \cdot 3) \mathrm{abc}$ & 1160 ah & $26.7 \mathrm{bc}$ \\
\hline Malathion & 25() & $31(5 \cdot 5)$ a & $2(1 \cdot 8)$ a & $61(7 \cdot 3)$ ab & $6(2 \cdot 3) \mathrm{d}$ & $1490 a b$ & $24 \cdot 4$ bc \\
\hline Fenitrothion & 250 & $25(5 \cdot 0)$ a & $1(1 \cdot 4)$ a & $39(6 \cdot 2) \quad a b$ & $l(0 \cdot 7) \quad a b$ & $1130 \mathrm{ab}$ & $23 \cdot 2 \mathrm{~b}$ \\
\hline Quinalphos & 250 & $24(4 \cdot 9)$ & $4(2 \cdot 1)$ a & $4 l(6 \cdot 3)$ ab & $3(1 \cdot 7)$ & $1120 \mathrm{ab}$ & $28 \cdot 8 c$ \\
\hline Endosulfan & 25() & $23(4 \cdot 7)$ a & $1(1 \cdot 2)$ & $46(6 \cdot 7)$ ab & $3(1 \cdot 7) \mathrm{c}$ & $1250 \mathrm{ab}$ & $26 \cdot 1$ bc \\
\hline Neem extract & 500 & $27(5 \cdot 2) \quad a$ & $8(2 \cdot 7) \quad b$ & $44(6 \cdot 6) \quad a b$ & $51(7 \cdot 1) \mathrm{c}$ & 900 ab & $25 \cdot 1 \mathrm{bc}$ \\
\hline Dichlorvos & 250 & $24(4 \cdot 8)$ & $4(2 \cdot 1)$ & $89(9 \cdot 2) \quad b$ & $4(2 \cdot 0)$ cd & 6()() ab & $22 \cdot 1 \mathrm{~b}$ \\
\hline Untreated check & - & $25(5 \cdot 0)$ & $22(4 \cdot 8) b$ & $73(8.5) b$ & $77(8 \cdot 8) \quad\lceil$ & 350 a & $16.4 \mathrm{a}$ \\
\hline $\mathrm{SE}$ & & $\pm(0 \cdot 28)$ & $\pm(0 \cdot 42)$ & $\pm(1 \cdot 12)$ & $\pm(0 \cdot 30)$ & $\pm 448 \cdot 4$ & $\pm 2 \cdot 01$ \\
\hline
\end{tabular}

- Figures in parentheses are the $\sqrt{n+T}$ transformed values. Figures followed by the same letter are not significantly different at $P=0) \cdot(05$

TABI.I: 2. Relative effectiveness of two sprays of five insecticides for head bug control in sorghum hybrid CSH 1 (1983 rainy season)

\begin{tabular}{|c|c|c|c|c|c|c|c|}
\hline \multirow[b]{3}{*}{ Insecticide } & \multirow[b]{3}{*}{$\begin{array}{l}\text { Dosage } \\
\text { (g a.i./ha) }\end{array}$} & \multicolumn{4}{|c|}{ No. of head bugs per panicle } & \multirow[b]{3}{*}{$\begin{array}{l}\text { Grain yicld } \\
\text { (kg/ha) }\end{array}$} & \multirow[b]{3}{*}{$\begin{array}{c}\text { 1000-grain mass } \\
\text { (g) }\end{array}$} \\
\hline & & \multicolumn{2}{|c|}{ Complete-anthesis } & \multicolumn{2}{|c|}{ Milk stage } & & \\
\hline & & Before spray & $24 \mathrm{~h}$ after spray & Before spray & $24 \mathrm{~h}$ after spray & & \\
\hline Carbary! & 500 & $13(3 \cdot 3)^{*} a$ & $1(1 \cdot 4)^{\star} \mathrm{a}$ & $18(4 \cdot 2)^{*} b$ & $2(1 \cdot 2)^{\star} a$ & $2400 \mathrm{a}$ & $27 \cdot 8 \mathrm{~b}$ \\
\hline Fenvalerate & 50 & $8(2 \cdot 6)$ & $1(1 \cdot 4) \quad a$ & $26(5 \cdot 0) \mathrm{b}$ & $5(2 \cdot 3)$ a & $2360 \mathrm{a}$ & $27 \cdot 0 \mathrm{~b}$ \\
\hline Chlorpyrifos & 250 & $13(3 \cdot 3)$ a & $5(2 \cdot 3)$ b & $16(2 \cdot 9)$ & $19(3.9) \quad b$ & $2350 \mathrm{a}$ & $24 \cdot 7$ ab \\
\hline Quinalphos & 250 & $9(2 \cdot 8)$ & $2(1 \cdot 5)$ ab & $19(4 \cdot 1) a b$ & $5(1 \cdot 8)$ a & 2040 a & $27 \cdot 1 \mathrm{~b}$ \\
\hline Malathion & 250 & $11(2 \cdot 6) \mathrm{a}$ & $2(1 \cdot 6)$ ab & $19(4 \cdot 2) b$ & $7(2 \cdot 4)$ a & $2030 \mathrm{a}$ & $24 \cdot 3 \mathrm{ab}$ \\
\hline Untreated check & - & $9(2 \cdot 4)$ & $1(1 \cdot 4) \quad a$ & $26(4 \cdot 9) b$ & $54(7 \cdot 3) \mathrm{c}$ & $1800 \mathrm{a}$ & $23 \cdot 3 a$ \\
\hline SE & & $\pm(0 \cdot 74)$ & $\pm(0 \cdot 30)$ & $\pm(0 \cdot 44)$ & $\pm(0.52)$ & $\pm 312 \cdot 4$ & $\pm 1 \cdot 33$ \\
\hline
\end{tabular}

- As Table 1 
TAB1.: 3. Relative effectiveness of two sprays of four insecticides for head bug control an sorghum hybrid CSH I (1984 ramy stasen)

\begin{tabular}{|c|c|c|c|c|c|c|c|c|c|c|c|}
\hline \multicolumn{12}{|c|}{ No of head hugs pamile } \\
\hline & \multicolumn{4}{|c|}{ Cuslocints ungustatur } & \multicolumn{3}{|c|}{ Camplammasp } & \multicolumn{2}{|c|}{ 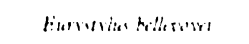 } & \multirow[b]{3}{*}{$\begin{array}{c}\text { (it:an youds } \\
\left(k_{t}: h d\right)\end{array}$} & \multirow[b]{3}{*}{$\begin{array}{l}\text { lonk1 prast } \\
\text { mass (R) }\end{array}$} \\
\hline & & Complets & anthesis & & Complete & anthesis & & $\| \alpha d-$ & louph & & \\
\hline Treatment & $\begin{array}{l}\text { Dosage } \\
\text { (g } 2.1 . / \mathrm{ha})\end{array}$ & Before spray & After spray & Milk stape & Before spray & Atier spersy & Milk stage & Before ypar & Allet spray & & \\
\hline $\begin{array}{l}\text { Demeton-S. } \\
\text { methỵl }\end{array}$ & 250 & $1(1 \cdot 0)^{\dagger} a$ & $1(1 \cdot 1)^{*} a$ & $\left.f(1 \cdot y)^{\dagger}\right]$ & $1(0.9)^{\dagger} \mathrm{a}$ & $1(1 \cdot 0)^{t} \mathrm{a}$ & $1(1-3) t$ & $i(1 \cdot f)^{\dagger}$. & $2(1.1)^{4} \mathrm{al}$ & $3 i+1$, & $30+16$ \\
\hline Monorotophos & 250 & $1(1 \cdot 1)$ a & $1(1 \cdot 1) \mathrm{d}$ & $+(1-9)$ a & $1(0 \cdot 4) \quad a$ & $1(1 \cdot 1) d$ & $111 \cdot 21)$ & $2(21)$ & $(1 \cdot i) d$ & $3.181) h$ & 28.31 \\
\hline Carbaryl & 500 & $1(1 \cdot 1)=$ & $1(1 \cdot 3)$ & $15(3.6)$.31 & $1(1 \cdot 4)$. & $1(1 \cdot 3) \mathrm{3}$ & $1(1 \cdot 3) a$ & $1(1 \cdot x) .1$ & $3(1 \cdot 8) \mathrm{h}$ & 3350 ahe & 24.54 \\
\hline Dimcthoatc & 250 & $2(1 \cdot 1) a$ & $1(1 \cdot 2) \mathrm{a}$ & $28(5-1)$ b & $1(1 \cdot 1)$. & $1(1 \cdot 2)$ & $1(1.4)$ & $\therefore(1.11)$ a & $1(1 \cdot y)$. & $31(11) .15$ & $34.5 \mathrm{ath}$ \\
\hline Lnereated check & - & $1(1) \cdot 9) \quad a$ & $+(2 \cdot 1) \quad b$ & $47(6 \cdot 8)$ & $2(1 \cdot 2) \cdot 1$ & $2(1 \cdot i) d$ & $1(11 \cdot 4) \quad a$ & $f(1.7) d$ & $3(2+3)$ & $284(1)$ & $2 x \cdot 6 \mathrm{a}$ \\
\hline SE: & & $\pm(0 \cdot 20)$ & $(1) \cdot 18)$ & $\pm(0.61)$ & $\pm(0 \cdot 18)$ & $\pm(1) \cdot 11)$ & $\cdot(1 \cdot 118)$ & $+(11 \cdot 3.4)$ & $\pm(1) \cdot 2 i)$ & $\pm 2(16 \cdot \pi$ & \pm 0.45 \\
\hline
\end{tabular}

- As Tablc 1

+ Figures in parentheses ate $\sqrt{n}$ transformed values

Taki. 4. Relative effectiveness of two sprays of four insecticides for head hug control in sorghum hybrad (SWII I (1985 rainy season)

Number of head bugs/pancle

Complcte anthesis

C. ungustutus Campvilommu sp.

Dosage

Treatment

Demeton-S-methyl

Carbaryl

Dimethoate

Monocrotophos

Untreated check

$\mathrm{SE}$

- As Table I

+ As Table 3

of Campylomma sp. were significantly reduced by all the insecticides, of which demeton-S-methyl was the most effective. The population of Campylomma sp. did not differ significantly at the milky stage among plots treated with different insecticides. During the hard-dough stage, a very high incidence of another head bug species, Eurystylus bellevoyei, was recorded. Dimethoate was most effective for $E$. bellevoyei, followed by demeton-S-methyl. The incidence of other panicle-feeding insects was low and did not differ significantly between different treatments. There were $18-40 \%$ of midge-damaged chaffy florets and $1-2 H$. armigera larvae per panicle. Grain yield was maximum in plots treated with demeton-S-methyl followed by those treated with monocrotophos, carbaryl and dimethoate. The 1000-grain weight was maximum in plots treated with demeton-S-methyl followed by those treated with carbaryl and dimethoate.

During the 1985 rainy season, plots treated with demeton-S-methyl had the lowest density of head bugs, followed by those treated with carbaryl (Table 4). Among other head bug species, the incidence of Campylomma sp. was high at the milky stage (1-3 bugs/panicle), and demeton-S-methyl and dimethoate were most effective against it. Among other paniclefeeding insects, the incidence of sorghum midge ranged from $27 \%$ to $42 \%$ and that of $C$. pallidus from two to four bugs per panicle. (irain yield was maximum in plots treated with demeton-S-methyl $(2430 \mathrm{~kg} / \mathrm{ha})$ followed by those treated with carbaryl $(2150 \mathrm{~kg} / \mathrm{ha})$. Thus, of the three systemic insecticides tested, demeton-S-methyl was the most effective for head bug control. Grain yield was higher in plots treated with demeton-S-methyl than in those treated with carbaryl, which was the most effective of the contact insecticides.

Dichlorvos, fenitrothion and monocrotophos were highly phytotoxic and caused burning and drying of entire leaves. Dimethoate caused slight drying of leaf margins and tips. These insecticides, therefore, should not be used for insect control in sorghum.

\section{Insecticide dosage required}

The head bug numbers at the complete-anthesis and milky stages were least in plots treated with carbaryl at $2000 \mathrm{~g}$ a.i./ha followed by those treated with $1000 \mathrm{~g}$ a.i./ha (Tables 5 and 6 ). The incidence of $C$. pallidus, E. bellevoyei, Campylomma sp. and $H$. armigera was less than one insect per panicle. Midge damage was $5-12 \%$ during the 1983 rainy season and $34-51 \%$ during the 1985 rainy season, and did not differ significantly between the treatments. The grain yield was highest in plots treated with $2000 \mathrm{~g}$ a.i./ha. 
TAвIL: 5. Effectiveness of different dosages of carbaryl under field conditions for head bug control in CSHI 1 (1983 rainy season)

\begin{tabular}{|c|c|c|c|c|}
\hline \multirow[b]{2}{*}{$\begin{array}{l}\text { Dosage } \\
\text { (g a.i./ha) }\end{array}$} & \multicolumn{2}{|c|}{ No. of head hugs/panicle } & \multirow[b]{2}{*}{$\begin{array}{c}\text { Grain yicld } \\
(\mathrm{kg} / \mathrm{ha})\end{array}$} & \multirow[b]{2}{*}{$\begin{array}{c}\text { 1000-grain } \\
\text { mass (g) }\end{array}$} \\
\hline & $\begin{array}{l}\text { Complete- } \\
\text { anthesis }\end{array}$ & $\begin{array}{l}\text { Milk } \\
\text { stage }\end{array}$ & & \\
\hline 250 & $14(3.6)^{*} b c$ & $5(2 \cdot 3)^{*}$ ab & $1790 \mathrm{ah}$ & $29.9 c$ \\
\hline 500 & $12(3 \cdot 2)$ bc & $7(2 \cdot 6) \quad b$ & $1720 \mathrm{ab}$ & $25.4 \mathrm{ab}$ \\
\hline 1000 & $6(2 \cdot 3) \mathrm{ab}$ & $3(1 \cdot 6)$ & $1720 \mathrm{ab}$ & $26 \cdot 3 \mathrm{abc}$ \\
\hline 2000 & $2(1 \cdot 1) \quad a$ & $3(1 \cdot 6)$ a & $2350 \mathrm{~b}$ & $28.4 \mathrm{bc}$ \\
\hline $\begin{array}{l}\text { Untreated } \\
\text { check }\end{array}$ & $17(4 \cdot 1) \mathrm{b}$ & $25(5 \cdot 0) \mathrm{c}$ & $1170 \mathrm{a}$ & $23 \cdot 3 \mathrm{a}$ \\
\hline SE & $\pm(0.65)$ & $\pm(0 \cdot 32)$ & $\pm 245 \cdot 8$ & $\pm 1 \cdot 54$ \\
\hline
\end{tabular}

As rible 1

\section{Optimum stage of panicle development for spraying}

Plots sprayed at the complete-anthesis stage had fewer head bugs at that stage than those treated at the topanthesis or milky stages. More bugs were recorded at the milky stage in plots treated at the top-anthesis stage. The incidence of other head bug species and $H$. armigera was negligible. Midge damage was $13-15 \%$ and $26-30 \%$ during the rainy season of 1983 and 1985 , respectively. Grain yield and 1000-grain mass were also maximum in plots treated at complete-anthesis (Tables 7 and 8 ). Sprays applied at the top-anthesis stage were effective only against the adults; the head bug population built up substantially from the nymphs emerging from the eggs laid in the glumes before spraying and through the migrating adults, and this resulted in considerable damage to the grains. Although delayed application at the milk stage controlled the head bugs, a substantial amount of damage had already been inflicted on the tender grains before spraying. Sprays applied at the completeanthesis stage provided maximum protection against head bug damage.

\section{Number of sprays required}

Head bugs were effectively controlled in plots treated with two sprays of carbaryl (Tables 9 and 10). The incidence of $C$. pallidus, Campylomma sp. and $H$. armigera was less than one insect per panicle. Midgedamaged chaffy florets ranged from $5 \%$ to $7 \%$ during

TABI.I: 6. Effectiveness of different dosages of carbaryl for head bug control in CSH 1 (1985 rainy season)

\begin{tabular}{|c|c|c|c|c|}
\hline \multirow[b]{3}{*}{ Dosage (g. a.i./ha) } & \multicolumn{3}{|c|}{ No. of head bugs/panicle } & \multirow[b]{3}{*}{$\begin{array}{c}\text { Cirain yield } \\
(\mathrm{kg} / \mathrm{ha})\end{array}$} \\
\hline & Complete-anthesis & \multicolumn{2}{|c|}{ Milk stage } & \\
\hline & After spraying & Before spray & Aficr spray & \\
\hline 250 & $I(1 \cdot 4) \dagger b$ & $38(6 \cdot 1)^{*} \mathrm{c}$ & $2(1 \cdot 6)^{*} a$ & $1180 a$ \\
\hline 500 & $<1(1 \cdot 0) \quad a$ & $16(3.9) \mathrm{b}$ & $1(1 \cdot 3)$ a & $1250 a$ \\
\hline 1000 & $0(1 \cdot 0) \quad a$ & $7(2 \cdot 6) \quad a$ & $1(1 \cdot 2)$ & 1260 \\
\hline 2000 & $<1(1 \cdot 2) \quad a b$ & $3(1 \cdot 6)$ & $<1(1 \cdot 2)$ a & $2000 \mathrm{~b}$ \\
\hline Untreated check & $11(4 \cdot 0) \mathrm{c}$ & $75(8 \cdot 6) \mathrm{d}$ & $146(12 \cdot 2) b$ & 917 a \\
\hline $\mathrm{SH}$ & $\pm(0 \cdot 07)$ & $\pm(0 \cdot 39)$ & $\pm(0 \cdot 18)$ & $\pm(173 \cdot 0)$ \\
\hline
\end{tabular}

- As Table 3

t As Tiable 1

TABI.I: 7. Oprimum stage of panicle for insecticide application (carbaryl at $500 \mathrm{~g}$ a.i./ha for head bug control in CSH 1 (1983 rainy season)

\begin{tabular}{|c|c|c|c|c|c|}
\hline \multirow[b]{2}{*}{$\begin{array}{l}\text { Stage at } \\
\text { insecticide application }\end{array}$} & \multicolumn{3}{|c|}{ No. of head bugs/panicle } & \multirow[b]{2}{*}{$\begin{array}{l}\text { Grain yield } \\
\text { (kg/ha) }\end{array}$} & \multirow[b]{2}{*}{$\begin{array}{c}\text { 1000-grain mass } \\
(\mathrm{g})\end{array}$} \\
\hline & Top-anthesis & Complete-anthesis & Milk stage & & \\
\hline Top-anthesis & $1(1 \cdot 1)^{*} a$ & $11(3 \cdot 1)^{*} b$ & $30(5 \cdot 4)^{\star} a$ & $1820 \mathrm{ab}$ & $25 \cdot 1 \mathrm{a}$ \\
\hline Complete-anthesis & $1(1 \cdot 1)$ a & $1(1 \cdot 0) \quad a$ & $13(3.4)$ a & 2340 bc & $27 \cdot 2 \mathrm{~b}$ \\
\hline Milk stage & $2(1 \cdot 7)$ a & $2(1.4)$ & $17(4 \cdot 0)$ a & $2150 \mathrm{bc}$ & $26 \cdot 2 \mathrm{ab}$ \\
\hline Untreated check & $2(1 \cdot 7)$ a & $12(3 \cdot 4) b$ & $16(3 \cdot 8)$ a & $1630 a$ & $24 \cdot 3$ a \\
\hline SF & $\pm(0 \cdot 24)$ & $\pm(0 \cdot 48)$ & $\pm(0 \cdot 79)$ & \pm 150 & \pm 0.73 \\
\hline
\end{tabular}

- As Table 1

TAні.ł: 8. Optimum stage of panicle for insecticide application (carbaryl at $500 \mathrm{~g}$ a.i./ha) for head bug control in CSH 1 ( 1985 rainy season)

\begin{tabular}{|c|c|c|c|c|c|}
\hline \multirow{2}{*}{$\begin{array}{l}\text { Stage at } \\
\text { insecticide application }\end{array}$} & \multicolumn{4}{|c|}{ No. of head bugs/panicle ${ }^{\star}$} & \multirow[b]{2}{*}{ Grain yield $(\mathrm{kg} / \mathrm{ha})$} \\
\hline & Top-anthesis & Complete-anthesis & Milk stage & Post-milk stage & \\
\hline Top-anthesis & $<1(1 \cdot 1) \dagger_{a}$ & $4(2 \cdot 2)^{\dagger} b$ & $22(4 \cdot 8)^{\dagger} b$ & $82(8 \cdot 7) \dagger b$ & $800 a$ \\
\hline Complete-anthesis & $7(2 \cdot 8) \quad b$ & $1(1 \cdot 1) \quad a$ & $1(1 \cdot 2)$ & $2(1 \cdot 4) \quad a$ & $1580 \mathrm{~b}$ \\
\hline Milk stage & $5(2.4) \quad b$ & $15(3.9) \mathrm{c}$ & $<1(1 \cdot 1)$ a & $1(1 \cdot 1) \quad a$ & $1460 \mathrm{~b}$ \\
\hline Untreated check & $14(3 \cdot 8) \mathrm{c}$ & $11(3 \cdot 3) \mathrm{c}$ & $51(7 \cdot 2) \quad c$ & $61(7 \cdot 6) \quad b$ & 510 a \\
\hline $\mathrm{SE}$ & $\pm(0 \cdot 19)$ & $\pm(0 \cdot 27)$ & $\pm(0 \cdot 21)$ & $\pm(1 \cdot 03)$ & $\pm 155 \cdot 4$ \\
\hline
\end{tabular}

- After spray

+ As Table 
TAнı.F 9. Number of carbaryl (at $500 \mathrm{~g}$ a.i./ha) sprays required for head bug control in CSH 1 (1983 rainy scason)

\begin{tabular}{|c|c|c|c|c|c|}
\hline \multicolumn{6}{|c|}{ No. of head bugs/panicle } \\
\hline No. of sprays & Top-anthesis & Complete-anthesis & Milk stage & Grain ỵicld $(\mathrm{kg} / \mathrm{ha})$ & 1000)-grain mass (g) \\
\hline One & $1(1 \cdot 3)^{*} a$ & $1(1 \cdot 0)^{*}$ & $18(4 \cdot 0)^{*} b$ & 26() $0 \mathrm{~h}$ & $24 \cdot 0 a$ \\
\hline Two & $1(1 \cdot 1)$ a & $1 \cdot 1(1 \cdot 0)$ a & $24(4 \cdot 3) \quad b$ & $2630 \mathrm{~b}$ & $28 \cdot 5 \mathrm{~b}$ \\
\hline Three & $1(1 \cdot 1)$ a & $1(1 \cdot 0)$ & $4(1 \cdot 8)$ & $25.40 \mathrm{~h}$ & $20 \cdot 0$ ab \\
\hline Untreated check & $3(1.9) \quad b$ & $21(4 \cdot 4) b$ & $29(5.4) \quad b$ & 1910 a & $25 \cdot 6$ ab \\
\hline SE & $\pm(0 \cdot 10)$ & $\pm(0 \cdot 32)$ & $\pm(0 \cdot 61)$ & $\pm 208 \cdot 3$ & $\pm 1 \cdot 17$ \\
\hline
\end{tabular}

- As Table 1

1.ABl.: 10. Number 'of insecticide sprays (carbaryl at $500 \mathrm{~g}$ a.i./ha) required for head bug control (1985 rainy stason)

\begin{tabular}{|c|c|c|c|c|}
\hline \multirow[b]{2}{*}{ No. of sprays } & \multicolumn{3}{|c|}{ No. of head bugs/panicle } & \multirow[b]{2}{*}{$\begin{array}{c}\text { Grain yield } \\
\text { (kg/ha) }\end{array}$} \\
\hline & $\begin{array}{c}\text { Top. } \\
\text { anthesis }\end{array}$ & $\begin{array}{l}\text { Complete- } \\
\text { anthesis }\end{array}$ & $\begin{array}{l}\text { Milk } \\
\text { stage }\end{array}$ & \\
\hline One & $<1(1 \cdot 1)^{*} a$ & $4(2 \cdot 2)^{*} \mathrm{~b}$ & $22(4 \cdot 8)^{*} b$ & $1390 \mathrm{~b}$ \\
\hline Two & $<1(1 \cdot 1)$ a & $<1(1 \cdot 1)$ a & $2(1 \cdot 7)$ a & $1550 \mathrm{~b}$ \\
\hline Three & $1(1 \cdot 2) a$ & $1(1 \cdot 2)$ a & $1(1 \cdot 2)$ a & $1490 \mathrm{~b}$ \\
\hline $\begin{array}{l}\text { Untreated } \\
\text { check }\end{array}$ & $14(3 \cdot 8) \quad b$ & $11(3 \cdot 3) \mathrm{c}$ & $51(7 \cdot 2)$ & $510 \mathrm{a}$ \\
\hline SE & $\pm(0 \cdot 14)$ & $\pm(0 \cdot 21)$ & $\pm(0.23)$ & $\pm 102 \cdot 5$ \\
\hline
\end{tabular}

As Table 1

the 1983 rainy season and $35 \%$ to $51 \%$ during the 1985 rainy season, and did not differ significantly among the treatments. Grain yield and 1000-grain mass was maximum in plots sprayed twice at the completeanthesis and milk stages. Two sprays of carbaryl applied at the complete-anthesis and milk stages thus seem to be sufficient for effective head bug control.

\section{Discussion}

Carbaryl was found to be the most effective of the contact insecticides, followed by fenvalerate, chlorpyrifos and quinalphos. These insecticides (except fenvalerate) had earlier been reported to control head bugs (David et al., 1969; Paul et al., 1983). Of the systemic insecticides, demeton-S-methyl was the most effective, and was superior to carbaryl. Because of the sucking type of feeding behaviour of head bugs, the insects also imbibed translocated/absorbed residues of the systemic insecticide; this possibly led to a better control through demeton-S-methyl compared with carbaryl. These insecticides belong to three different insecticide groups: carbamates (carbaryl); organophosphates (demeton-S-methyl) and synthetic pyrethroids (fenvalerate), with different modes of action. These insecticides should, therefore, be used alternatively for effective head bug control, to avoid the development of insecticide-resistant bug populations. With regard to the other insects feeding on the sorghum panicle, the percentage of midge-damaged chaffy florets tended to be higher. The insecticide sprays were not effective against midge because midge eggs and larvae remain protected inside the glumes. Oviposition by the sorghum midge occurred before spraying and thus the differences in midge damage were not significant. Plots treated with $2000 \mathrm{~g}$ a.i./ha differed significantly in grain yield from those treated with $250-1000 \mathrm{~g}$ a.i./ha. However, an application rate of $2000 \mathrm{~g} \mathrm{a.i./ha}$ is too high whereas $500 \mathrm{~g}$ a.i./ha gives effective control of head bugs and compares favourably with other insecticides. Since damage by head bugs is both quantitative and qualitative, further studies should be carried out to determine an optimum dosage for application. Insecticide application at the complete-anthesis stage proved to be most effective because it coincided with the emergence of first-instar nymphs from the glumes. Two applications are necessary to control head bugs to prevent quantitative and qualitative losses in grain yield.

\section{Conclusions}

Carbaryl, fenvalerate and demeton-S-methyl are effective for head bug control in sorghum. Two applications of insecticides at the complete-anthesis and milky stages suffice for head bug control.

\section{Notes and acknowledgements}

Our thanks are due to Ms V. D. Kamath, Mr K. J. Chari and $\mathrm{Mr} \mathrm{D}$. Krishna for their assistance in carry. ing out this work. We also thank Dr D. Dent, Dr J. A. Wightman, Dr W. Reed, and Dr P. W. Amin for reviewing the manuscript.

Approved as Journal Article No 662 by the International Crops Research Institute for the Semi-Arid Tropics (ICRISAT) Patancheru PO, 502324 AP, India.

\section{References}

Chlizian, M. C., Kylasam, M. S. ANd Krishna, P. S. (1941). Further studies on Calocoris angustatus. Madras Agriculture fournal 29, 66-69.

David, V. B., Sivagami, R. AND Janagarajan, A. (1969). A schedule for treatment against stemborer and earheadbug; pests of Vellaicholam. Madras Agriculture fournal 56, 785-789.

Paul, M. D., Subba Rao, D. V. and Narayana, K. L. (1983). Evaluation of insecticides as sprays and dusts for the control of sorghum earhead bug (Calocoris angustatus L.). Indian fournal of Plant Protection 11, 13-16.

PUTTARUdRAiah, M. (1947). Field control of earhead pests of jola (Andropogon sorghum). Mysore Agriculture Journal 25, 48-53. 
SHAR.MA, H. C. (1985). Screening for mirid headhug resistance in sorghum. In: Proceedings of the International Sorghum Entomology W'orkshop, 16-21 July 1984. Texas A und M University, Collegc Station, Texas, USA, pp. 317-336. Patancheru, 502 324, AP India: ICRISAT.

Sharma, H. C., LFeschner, K., SANKaraM, A. V. B., Gunasteklar, D., Marthandame'RTHI, K., Bhaskakiah, M. AND StlitaNA, N. (1984). Insect antifeedants and growth inhibitors from Azadirachta indicu and Plumbago aevlanica. In: Natural Pesticides from the Neem Tree and Other Tropical
Plants, pp. 291-320 (ed. by H. Schmutterer and K. R. S. Ascher). Fschborn, Federal Republic of Germany: Deutsche Gesellschaft für Technische Zusammenarbeit (GTZ).

Received 2 February 1987

Accepted 23 March 1987 